\title{
Law Of Moving Object Assurance Contract In Consumer Financial In Indonesia
}

\author{
Dr (cand). T. Muhammad Ali Bahar, SH., M.Kn. \\ (Legal science doctoral student, Faculty of Law, University of Sumatera Utara, Medan, Indonesia) \\ Prof. Dr. Tan Kamelo, SH, MS \\ (Promotor) \\ Prof. Dr. Suhaidi, SH, MH \\ (Co Promotor) \\ Dr. OK. Saidin, SH, MH \\ (Co Promotor)
}

\begin{abstract}
Aabstract:The grant of financial from financial institution is basically similar to credit grant by bank, in consumer financial institution, assurance is necessary to assure that the debtor is able to fulfill his obligation according to the financial contract signed by the parties. Beside trust assurance, in financial contract, material assurance contract is also done in moving object in fiduciary contract. It is regulated in Fiduciary Act, as moving object assurance contract institution on the basis of trust, with the provision that the object which ownership is to be transferred, will still under the authority of the owner or debtor. The certificate of fiduciary is made in Indonesian in front of Notary, and in order to use publicity principle for the creditor as the fiduciary receiver then Fiduciary certificate must be registered in Fiduciary Registration office so that the fiduciary has executorial power, similar to the verdict with its legal power. Financial institution as creditor on its own authority can execute the assurance object of the consumer/debtor for paying the debt if there is some failure in fulfilling the contract from the debtor side. Fiduciary contract provides the owner with a preliminary right or preferential right. It is a fiduciary right receiver to take the payment of the debt on execution of the fiduciary object. This right will not be lost by bankruptcy or liquidation of the debtor.
\end{abstract}

Keywords: contract, assurance, financial, fiduciary.

\section{INTRODUCTION}

Financial institution is one of the business in non bank financial institution which has a very important role in financial. The activity is including the funding or access of capital by not pulling direct fund from the society in giro, deposit, saving, and promissory notes to pay. According to the activity conducted by the financial institution, financial institution has a very important role as one of the potential alternative financial source to improve national economic growth.

Wisdom package by Indonesian government issued in 20 December 1988 started to introduce financial institution which is not only in rental, but also including other financial business. Wisdom package of 1988 was put in Presidential Decree number 61 of 1988 regarding Financial Institution and Financial Ministry Decree Number 1251/KMK013/1988 regarding the provision and procedure of Financial Institution Practice. Based on this provision, financial institution is including six business: leasing, venture capital, factoring, consumer finance, credit card, securities company. Financial institution mentioned in this writing, is consumer financial institution. Consumer finance is a financial activity for goods procurement based on consumer needs with financial system of installment payment by consumer. ${ }^{1}$ Financial by financial institution is basicly similar to credit grant by bank, in consumer financial institution, assurance is necessary to assure that the debtor is able to fulfill his obligation according to the financial contract signed by the parties. Beside as assurance that consumer will be able to fulfill his obligation, in financial contract, agreement is also done in material assurance especially in moving object such as in vehicle bought by consumer in the financial business. The contract which is the object of this issue is done by making some addition contract which is fiduciary assurance grant agreement which follow the main contract, consumer financial. Basically, in implementing consumer financial contract in Indonesia, there is not only one contract made by the parties, but there are some others. The main contract is

1 Sunaryo (2008). Hukum Lembaga Pembiayaan, Jakarta: Sinar Grafika. p. 7 
consumer financial contract, but from this contract, there are some additional agreements such as material assurance contract.

Commonly, there are two kinds of assurance, individual and material. ${ }^{2}$ According to the character, assurance can be differed to common assurance and special assurance. Article 1131 Private Law Book in Indonesia reflected common assurance "any material right of the debtor, both moving or non moving object, both existed or to be existed, all become the responsibility for any individual contract". Then, stated in Article 1132 Private Law Book, "material right is becoming a group assurance for anyone has debt to them, the income of the sale is divided according to balance, according to the amount of each debt, unless there is valid reasons to be put as priority". And special assurance is including individual assurance and material assurance. Individual assurance is one agreement between someone in debt or creditor with a third party who ensure the fulfillment of the obligations by the debtor. ${ }^{3}$ For example responsibility contract (Article 1820 Private Law Book), guarantee contract (Article 1316 Private Law Book) and joint liability contract. Common assurance is considered as insufficient and lack of security, because it can cause the creditor to regain his money or capital from the debtor. Because of that, the creditor can ask the creditor to procure additional agreement which is a special assurance, which appoint certain property of the debtor as the assurance of debt payment. ${ }^{4}$

Special assurance is commonly named as material assurance, that is an assurance providing right to the creditor on one property of the debtor, which is the right to use the property if the debtor fail to fulfill what has been agreed in the contract. Material assurance is including pawn right, mortgage, and fiduciary. According to Stein in his book, J. Satrio mentioned that in the beginning of Private Law Book, pawn assurance institution and mortgage were indeed sufficient for assurance practice. At the time, credit activity has not developed and pawned properties were artwork and jewelry. At this moment, one of the form of material assurance used is fiduciary assurance which is for moving object assurance contract. ${ }^{5}$

Moving object assurance or fiduciary contract in Indonesia has been regulated in Indonesian Act number 42 of 1999 regarding Fiduciary in 30 September 1999 and Indonesian Government Regulation number 86 of 2000 regarding the procedure of fiduciary registration and Fiduciary certificate making in 30 September 2000. After this, it is sufficient to be written in Fiduciary Assurance Act. The moving object assurance contract with fiduciary assurance will provide the fiduciary holder a preferential right from the receiver. Preferential right is a fiduciary right receiver to take the payment of the debt on execution of the object which is fiduciary assurance. Preferential right from the fiduciary receiver will not be lost because of bankruptcy or liquidation of the debtor.

The main issue in this paper is the Law in moving object assurance contract in Financial. Moving object assurance contract here means a moving object assurance contract in fiduciary as regulated in Law Fiduciary. The method used is legal normative.

\section{DISCUSSION}

Law Regarding Moving Object Assurance Contract in Financial

Fiduciary Contract is included in formal agreement, because according to Article 5 Fiduciary Act, the imposition of object with fiduciary assurance is made with notary deed in Indonesian and it is Fiduciary deed. The deed is to be registered in Fiduciary Registration Office as regulated in Article 11 (1) and then Fiduciary Certificate can be issued.

Fiduciary assurance contract grant is similar to other assurance contract, which is an accessory agreement, as asserted in Article 4 Fiduciary Act, that "Fiduciary is a secondary agreement to a principal agreement that creates any obligation for the parties to perform". Accessory agreement has the character of non individual, its duration of effect depends on the main contract.

Similar to other debt assurance agreement, pawn contract, mortgage or responsibility right, fiduciary agreement is also an accessory agreement. It means that it is not individual, but it follows other agreement which is the main agreement. In this matter, the main agreement is the debt. Because of that, the consequence of this accessory agreement is that if the main agreement is invalid, legally, the fiduciary contract as accessory agreement is also invalid. ${ }^{6}$

2 Tan Kamelo (2004). Hukum Jaminan Fidusia, Suatu Kebutuhan Yang Didambakan. Bandung: PT. Alumni, p. 2.

3 R. Subekti (1989). Jaminan-jaminan Untuk Pemberian Kredit Menurut Hukum Indonesia. Bandung: PT. Citra Aditya Bakti. p.15.

$4 \quad$ Ibid., p. 31.

5 J. Satrio (1993). Hukum Jaminan, Hak-Hak Jaminan Kebendaan. Bandung: Citra Aditya Bakti. p. 9.

6 Munir Fuady (2003). Jaminan Fidusia. Bandung: PT. Aditya Bakti, Bandung. p. 19. 
According to Article 1 (1) Act number 42 of 1999 regarding Fiduciary, Fiduciary is a transfer of ownership of an object on trust with the provision that transferred ownership of the object remains in the control of the owner of the object.

Some characters seen in the formulation are:

a. Ownership transfer of an object;

b. Based on trust;

c. The object is under the authority of the owner. ${ }^{7}$

The ownership transfer is the property of the assurance object is transferred to the creditor by the owner, so that the ownership is in the authority of the creditor or receiver. Based on trust definition is not in any explanation in Fiduciary Act. The word 'trust' has the meaning that the granter of assurance believe or trust that the transfer of the property is not intended to make the property really belong to the creditor, if their contract is complete, then the property will be back to be under the debtor'sauthority. Under the authority of the owner means that the transfer is done in contitutum possesorium way, means that its done with promise that the object, will be physically under the authority of the granter, so the property is held by the debtor or owner. ${ }^{8}$

According to V. Oven as cited by J. Satrio, the transferred one is the legal right of the object. By that, the right to use the object will still be in the granter's. in this matter, the legal right is for the creditor, but the social right is in the debtor. ${ }^{9}$

Fiduciary assurance of property right transfer is intended to be merely as assurance in paying the debt, not to be owned by the receiver. This is powered by Article 33 Fiduciary Assurance Act which stated that every promise which provide authority to the fiduciary receiver to own the object when the debtor fail to complete the contract will be cancelled by law/ the fiduciary assurance object has been regulated in Article 1 (4), Article 9, Article 10 and 20 in Fiduciary Act. ${ }^{10}$

In Fiduciary Act, there are some requirements which must be fulfilled by fiduciary agreement contract such as: 1. Imposition and Registration of Fiduciary

Article 4 of Fiduciary Act stated that Fiduciary is a secondary agreement to a principal agreement that creates any obligation for the parties to perform. The definition of "performance" in this provision is to give something, do something, or not do something, which can be valued in monetary terms. An object imposition with fiduciary is regulated in Article 5 Fiduciary Act, which are:

(1) Imposition of a Fiduciary over objects is made by notarial deed in the Indonesian language and is a Fiduciary deed.

(2) For the Fiduciary deed referred to in paragraph (1), the fee amount shall be further regulated by Government Regulation.

Fiduciary Act must fulfill these requirements: in notary deed, in Indonesia, contain at least these requirements:

a. Fiduciary granter identity (complete name, religion, address, date and place of birth, sex type, marriage status, occupation)

b. Fiduciary receiver identity, regarding the fund as stated above;

c. Day, date, and hour of the fiduciary deed making;

d. Main agreement data guaranteed by fiduciary;

e. Explanation regarding the object of fiduciary, regarding the object identification, and the ownership verification letter. If the object is constantly changing such as in inventory, the variety, brand, and quality of the object must be mentioned.

f. The value of the assurance;

g. The value of the fiduciary assurance object.

According to Munir Fuady, if there is an evidence of Fiduciary Certificate and it is indeed valid, the other evidence in any form must be rejected. Verification by the parties by only showing the Fiduciary Deed made by the notary is not sufficient because, according to Article 14 (3) Fiduciary Act number 42 of 1999, with the

7 J. Satrio. (2002). Hukum Jaminan Hak Jaminan Kebendaan Fidusia. Bandung: PT. Citra Aditya Bakti, p. 159.

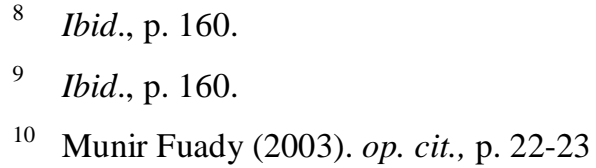


existence of fiduciary assurance act, fiduciary institution is not considered born. The birth of fiduciary is when it is registered in fiduciary registration. ${ }^{11}$

The fiduciary assurance registration in Article 11 Fiduciary Act stated that:

(1) Objects encumbered with Fiduciary must be registered.

(2) In the event that objects are encumbered with Fiduciary outside the territory of the Republic of Indonesia, the obligation referred to in paragraph (1) remains in effect.

According to Article 12 and 13 Fiduciary Act, fiduciary assurance registration is at Fiduciary Registration office. If the office is not existed in a county or district, then the registration is in the Law and Human Right Department territorial office in the province.

The one who s rightful to register the fiduciary assurance is the receiver of the fiduciary, the proxy or its representation, by attaching fiduciary registration statement, containing:

a. Identity of the fiduciary granter and receiver;

b. The date of fiduciary assurance deed, name and place of the notary made the fiduciary assurance deed;

c. Main contract data of the fiduciary assurance object;

d. The value of the assurance; and

e. The value of the object.

Fiduciary registration office will then record the fiduciary assurance in Fiduciary List Book on the same date with the registration accepted. The date is considered as the birth date of the fiduciary assurance. In that day also, fiduciary registration office in territorial office in province (if not existed in county/district) will issue a fiduciary assurance certificate to the applicator or fiduciary receiver.

In this certificate, the sentence of "In the Name of Justice Based on the Belief in the one and only God" is mentioned. The certificate has executorial value which is similar to the verdict of court with legal power. It means that this certificate can be directly execute the object without the need of trials and investigations through the court and it has the character of final and binding the parties to do the verdict. According to the provision in Article 5 Government regulation of Indonesia number 86 of 2000 regarding the Procedure of Fiduciary Registration and the Fee of Fiduciary Deed making, it was stated that when some failure in writing in the Deed accepted by the applicator happens, in at latest 60 days after the acceptance, the applicator must inform the office to issue revised certificate. The certificate issuance is for free.

\section{Preferential Right of the Fiduciary}

Preferential right of the fiduciary receiver has been regulated in Article 27 (2) Fiduciary Act, that preferential right is tThe right of the Fiduciary receiver to settle their claims against the proceeds of execution of the Fiduciary object. Regarding the position of preferential right of the receiver, if the debtor is in bankruptcy or liquidation, it has been regulated in Article 27 (3) Fiduciary Act that "The right of precedence of the Fiduciary receiver is not discharged due to the bankruptcy and liquidation of the Fiduciary giver".

By that, it the debtor is in bankruptcy or liquidation, the receiver (creditor) will be the first to be paid, taken by the sale of fiduciary object, the rest of the sale is what will be given to the other creditors. Regarding the possibility of more than one fiduciary of one object, according to Article 28 of Fiduciary Act, the preferential right is given to the first registered right in Fiduciary Registration Office.

According to Munir Fuady, there is no preferential right to the second fiduciary receiver with the reasons of:

a. If the registration system is run well and right there will be no possibility for the second fiduciary registration;

b. If the fiduciary is not registered, the non registered fiduciary is actually non exist because the fiduciary is considered to be born after the registration;

c. Because re-fiduciary is forbidden by Fiduciary Act number 42 number $1999 .^{12}$

3. The Assignment and Abolishment of Fiduciary

The transfer of fiduciary assurance is regulated in Article 19 until Article 24 Fiduciary Act, Article 19 stated that: ${ }^{13}$

a. The right transfer on the debt ensured with fiduciary caused the transfer of any right and obligation of fiduciary by law to the new creditor.

b. The transfer of fiduciary assurance is registered to the new creditor to the Fiduciary Registration Office.

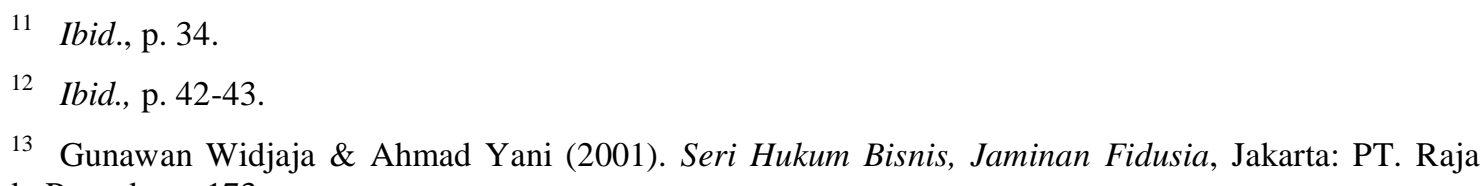
Grafindo Persada. p. 173. 
A cession, which is a debt transfer done with authentic deed or signed deed. To transfer means to sell or lease for the business. The right transfer of debt with fiduciary assurance can be transferred by the fiduciary receiver to new fiduciary (new creditor). New creditor is the one who do the registration regarding the transfer of fiduciary assurance to Fiduciary Assurance office. ${ }^{14}$

With this, any right and obligation of fiduciary receiver is transferred to the new one and the right transfer of the debt is to be conveyed to the fiduciary granter. The fiduciary granter is forbidden to transfer or pawn the object to other party, because the character of the fiduciary is binding the object to be under the authority of the owner. The exception of this provision is that fiduciary granter can transfer the object of fiduciary. ${ }^{15}$ If the transfer of main contract regulated in the debt guaranteed with fiduciary, it caused the transfer of any right and obligation by law to the new creditor. The new creditor must also register to the fiduciary registration office.

Beside transferable, it can also be deleted. The deletion of fiduciary means the invalid term of fiduciary. There are three causes of the deletion of the fiduciary as regulated in Article 25 of Fiduciary Act which are:

a. The deletion of the debt ensured with fiduciary because of payment with explanation from the creditor;

b. The release of fiduciary assurance right by fiduciary receiver or;

c. The deletion of the object, this is not deleting insurance claim. ${ }^{16}$

If the debt of the granter has been paid, it is the responsibility of the receiver or his proxy to convey in written for to the Fiduciary Registration Office that the debt has been paid. This is done at latest 7 days after the deletion of the related fiduciary attached with supporting documents regarding the deletion of the fiduciary. With this, there are two things to be done by the office which are:

a. At the same time to mark the fiduciary assurance list from the fiduciary list book; and

b. At the same time with the mark, to issue an explanation letter which state that the fiduciary assurance certificate is no longer valid. ${ }^{17}$

The deletion of the fiduciary because of the paid debt ensured with fiduciary is as the consequence of the fiduciary assurance contract as an accessory contract from its main contract. With the deletion of the object, the assurance of fiduciary is also deleted because there is no use for it anymore. But if the object is in insurance and then it is broken or damaged because of certain incident, the insurance claim can be used as the substitute of the object and accepted by the fiduciary receiver, because according to Article 10 and Article 25 Act of Fiduciary Assurance, the fiduciary assurance is including insurance claim, where the object can be insured and the damage cannot delete the insurance claim.

According to Article 25 (3) Fiduciary Act, the deletion of fiduciary assurance must be conveyed by the creditor to the fiduciary registration office by attaching statement regarding the deletion of the debt, release of the right on fiduciary assurance or the deletion of the object. This is the logical consequence from provision in Article 16 (1) which regulate that if there is some alteration regarding the issues attached in fiduciary assurance certificate, the fiduciary receiver must propose registration of the alteration to the fiduciary registration office.

By conveying to the office, the office will mark the fiduciary assurance reported in the fiduciary list book and issue an explanation regarding its invalidation. The goal of the procedure is to provide legal certainty to the society or third party that the object is no longer considered as Fiduciary assurance.

\section{Execution of Moving Object Bound with Fiduciary in Financial}

In debt relation, where there is the obligation to do something by the debtor and the right to receive by the creditor, the smoothness of the relation will be realized if each party fulfill their obligation. But in a relation where the debt is due, if debtor cannot fulfill his obligation voluntarily, creditor has the right to sue his payment (execution right) to the debtor property used as assurance. ${ }^{18}$

According to article 1238 Private Book of Law in Indonesia, failure by debtor, after warnings by creditor, must be considered as a complete failure, especially when its already due.

14 Salim H.S (2004). Perkembangan Hukum Jaminan Di Indonesia, Jakarta: PT. Raja Grafindo Persada, p. $87-88$.

15 Ibid., p. 88.

16 Ibid., hal. 88.

17 Ibid., p. 88-89.

18 Sri Soedewi Masjchon Sofwan (1980). Beberapa Pembuatan Usulan Penelitian, Sebuah Panduan Dasar, Jakarta: PT. Gramedia Pustaka Utama, p. 31. 
In Fiduciary Assurance Act, there is no such term used to describe failure, as written in Article 15 (3) which stated that when debtor is in failure, the fiduciary receiver has the right to sell the object on his own authority. In implementing the execution, Article 19 (1) of Fiduciary Act regulates that when Debtor or Fiduciary granter failed to fulfill his promise, the execution on the assurance object can be done by:

1. Title executorial implementing by Fiduciary receiver;

2. The sale of object of assurance under the authority of the Receiver with general bid and to take payment from the result;

3. Direct sale based on agreement by the granter and receiver to the related parties, and it is to be announced at least in 2 newspaper in the related territory.

In the practice, there is no mention in the Fiduciary Assurance Act but commonly the creditor can do the execution with charges to the court. ${ }^{19}$ One of the requirements so that the execution can be done is that in the deed, there is the sentence of "In the Name of Justice based on the belief of One and Only God"and a court verdict which has ultimate legal power, by asking so from the Head of the Court, to execute. Second, fiduciary execution partially with general execution (in bidding office) and it can be done without the involvement of the court. Third, fiduciary execution with parate execution (without the involvement of the court) by selling the object directly. The requirements are:

a. Done based on the agreement between the granter and receiver;

b. If done with direct sale which result highest price benefits the party;

c. Conveyed in written form by the granter and/or the receiver of fiduciary to the related parties;

d. Announced in at least 2 (two) newspaper in related territory;

e. The sale is done after one month since conveyed in written form. ${ }^{20}$

Regarding fiduciary execution with common charge, Munir Fuady said that even though it is not mentioned in Fiduciary Act, the creditor doesn'tdo the common execution procedure in the court. Because the existence of the Act of Fiduciary Act with special execution model is not to delete common practical law, but to add some provision in general practical law. ${ }^{21}$

To prevent some damage in execution according to Article 29 (1) Fiduciary Act, there is a prohibition as regulated in Article 32 that each promise to execute an object as fiduciary assurance by contradicting way with provisions as mentioned, will be canceled by law.

In the matter of the fiduciary granter is objecting the transfer of the assurance object in execution, the fiduciary receiver is entitled to take the object and even ask for assistance of authorized party. This is according to Article 30 Fiduciary Act, which stated that the fiduciary granter must give the object of assurance in execution. Then, in Article 34 it was stated that in the matter of the execution alone is not enough to pay the debt, then the rest is the responsibility of the debtor, and if the execution result is resulting more than the debt, the creditor must give the rest to the debtor.

\section{CONCLUSION}

The financial grant of the financial institution is basically similar to the grant of credit by bank, assurance is necessary to assure that the debtor is able to fulfill his obligation according to the financial contract signed by the parties. Beside trust assurance, in financial contract, material assurance contract is also done in moving object in fiduciary contract. Fiduciary is regulated in Fiduciary Act as the institution of moving object contract based on trust with the provision that that the object which ownership is transferable must be under the authority of the owner or the debtor. The Fiduciary Deed is made in Indonesian in front of Notary, and in order to use publicity principle for the creditor as the fiduciary receiver then Fiduciary assurance certificate must be registered in Fiduciary Registration office. This office records the Fiduciary in the Book of Fiduciary list in the same date as the registration acceptance, as the birth date of the fiduciary, and Fiduciary Certificate is conveyed to the applicator as the receiver, which contain the words of "In the Name of Justice based on the belief of One and Only God"so that the certificate has the executorial power similar to the court verdict with its ultimate legal power. Consumer Financial Institution under his own authority can execute the object for the payment if there is a failure by the consumer in fulfilling the contract. The fiduciary contract provides preferential right to the financial institution. It is a right to take the payment from the execution of the assurance object. This preferential right will not lost to a bankruptcy or the liquidation of the debtor.

\footnotetext{
19 Munir Fuady (2003). op. cit., p. 62.

20 Ibid., p. 62.

21 Ibid., p. 63.
} 


\section{BIBLIOGRAPHY}

[1]. Fuady, Munir (2003). Jaminan Fidusia. Bandung: PT. Aditya Bakti, Bandung.

[2]. H.S, Salim (2004). Perkembangan Hukum Jaminan Di Indonesia, Jakarta: PT. Raja Grafindo Persada.

[3]. Hasbullah, Frieda Husni (2002). Hukum Kebendaan Perdata Jilid 2 Hak-hak Yang Memberi Jaminan, Jakarta: Ind Hill-Co.

[4]. Satrio, J (1993). Hukum Jaminan, Hak-Hak Jaminan Kebendaan, Bandung: Citra Aditya Bakti.

[5]. Satrio, J. (2002). Hukum Jaminan Hak Jaminan Kebendaan Fidusia. Bandung: PT. Citra Aditya Bakti.

[6]. Sofwan, Sri Soedewi Masjchon (1980). Beberapa Pembuatan Usulan Penelitian, Sebuah Panduan Dasar, Jakarta: PT. Gramedia Pustaka Utama.

[7]. Subekti, R (1989). Jaminan-jaminan Untuk Pemberian Kredit Menurut Hukum Indonesia. Bandung: PT. Citra Aditya Bakti.

[8]. Sunaryo (2008). Hukum Lembaga Pembiayaan, Jakarta: Sinar Grafika.

[9]. Tan Kamelo (2004). Hukum Jaminan Fidusia, Suatu Kebutuhan Yang Didambakan. Bandung: PT. Alumni.

[10]. Widjaja, Gunawan \& Ahmad Yani (2001). Seri Hukum Bisnis, Jaminan Fidusia, Jakarta: PT. Raja Grafindo Persada. 